\title{
On the Innovation and Entrepreneurship Education of Undergraduate Tourism Management Specialty in Higher Vocational Education
}

\author{
Yuan Zhou \\ School of Tourism Management, Hainan Economic and Trade Vocational and Technical College, \\ Haikou, Hainan 571127, China
}

Keywords: vocational, undergraduate, tourism management, innovation and entrepreneurship education.

\begin{abstract}
With the development of the world economy, tourism has gradually entered people's life, tourism is also developing. After entering the twenty-first century, the tourism industry quickly became one of the largest emerging industries in the world. With the expansion of the scale, the tourism industry is also constantly evolving within the process of professionalization, vocational colleges have also set up tourism management professional. Undergraduate tourism management students through the school to learn, to receive innovative entrepreneurship education, for the development of tourism and related aspects of the improvement also played a considerable role in promoting. Therefore, the strengthening and improvement of the level of innovation and education of tourism management specialty in higher vocational colleges is not only the responsibility and obligation that campus education should bear, but also the trend of economic development and satisfying the overall demand of industry progress.
\end{abstract}

\section{Introduction}

Innovation is the economic development, scientific and technological progress inexhaustible motive force, entrepreneurship will inject new blood into the market, promote the development of the market, to maintain economic vitality. In human society, whether it is innovation or entrepreneurship, are inseparable from the role of talent, a deeper level that is the role of education. "Entrepreneurship education" was first proposed by the United Nations Educational, Scientific and Cultural Organization, the essence of which is the entrepreneurial spirit into the education process, cultivate students' entrepreneurial skills, improve entrepreneurship. This concept in the process of economic development is widely confirmed its correctness, but also in the world, the education of the reform and development of far-reaching impact. In terms of China, the introduction of entrepreneurial education concept and time more developed countries in terms of much later. By 2002, China was officially launched pilot entrepreneurship education. In fact, China's economic development requirements related to entrepreneurship, innovative talent gap than this time point to the morning many. For a long time, the educational goals of higher vocational colleges in our country are often aimed at employment. Correspondingly, the employment rate naturally becomes an indicator of the level of education that all the higher vocational colleges are looking at. However, at the same time, China's higher vocational colleges and universities graduate business rate of view, the number of fresh graduates choose the number of entrepreneurs, accounting for about $2 \%$ of the total number of graduates. This figure shows that there are problems in the innovation and entrepreneurship education of higher vocational colleges in our country, and there are big flaws in the cultivation of students' innovation ability and entrepreneurial ability. In recent years, China has promoted the cause of educational reform, especially in the education of higher vocational colleges, the development of innovation and entrepreneurship education, the state and the government to provide financial support for the development of innovation and entrepreneurship in colleges and universities, to encourage colleges and universities to set up relevant courses, Theoretical knowledge and practical operation of the combination of educational methods, in the education process into the concept of innovation, 
entrepreneurship, students' entrepreneurial skills and innovation, to encourage students to actively start.

\section{The reasons for the innovation and entrepreneurship education in higher vocational colleges}

\subsection{The rapid development of tourism}

From the world pattern, the tourism industry has grown from the formation to the development, and now entered a stable development period. Since the beginning of the 21 st century, tourism has ushered in its development of the second golden age. Tourism will develop into the world's largest industry, the size of tourists will be an unprecedented expansion, tourists from all over the world, across the race, national, political, economic and other factors, and jointly promote the development. On China's tourism industry, China's tourism industry in 2015 total revenue of 3.38 trillion Yuan, the country's total domestic tourism revenue of 3.43 trillion Yuan, to 2016, China's domestic tourism revenue of 3.9 trillion Yuan. In addition to the growth of tourism revenue, in the industry, there have been many innovative enterprises. The refinement of the tourism industry will also gradually shift the focus of tourism innovation to products and services. The products and services developed for different tourism characteristics make the tourism industry appear new situation, the emergence of innovative products and services to promote capital operation, promote economic development. At the same time, the emergence of industry innovation also requires the supply of the corresponding talent, which to higher vocational colleges and universities tourism management professional innovation and entrepreneurship education requirements.

\subsection{The demand for talent needs of the situation}

China's education reform in the continuous advance and in-depth, college innovation and entrepreneurship education reform and strengthening is one of the work focuses. In fact, innovation and entrepreneurship education is the background of the market demand for talent changes in the situation. Since the reform and opening up, China's economic situation has undergone enormous changes, the market needs of the talent are not just the relevant professional and technical staff. The intensity of competition in the market and the rapid changes in the market are required to innovate the ability of enterprises, in essence, is the ability of talent innovation requirements. Reflected in the education, we must improve the university students' innovative ability and entrepreneurial skills. This requirement is even more pronounced for the tourism industry, which is rapidly developing in the $21 \mathrm{st}$ century. Correspondingly, the progress of the innovation management education of tourism management in colleges and universities must conform to the trend of talent demand.

\subsection{Social employment pressure to ease}

In the past, the educational goals of higher vocational colleges in China are mainly based on the employment rate, and the employment rate of most schools shows that the number of graduates who choose to be employed after leaving the campus is the main factor. With the development of higher education, fresh graduates increased year by year, and the increase is very rapid, but the social position is limited, and the basic number of little change. In this case, the employment problems of college graduates will gradually appear, the employment pressure of graduates is increasing, the social employment situation is more and more serious, so how to effectively alleviate the employment pressure, to a certain extent, important. In fact, to carry out college students in innovation and entrepreneurship education can guide more graduates to actively start a new business and post, while reducing the competitive pressure of existing positions, effectively alleviate the employment problem. 


\section{The present situation and problems of the innovation and entrepreneurship education of Tourism Management Major in Colleges and Universities}

\subsection{Tourism management professionals training direction is not clear}

University tourism management professional aims to transport the development of China's tourism industry professionals, improve the current tourism business and management level. With the development of the industry, talent requirements are constantly changing, the moment, not only requires relevant professionals with excellent professional quality, but also need to have a good attitude, a positive attitude, healthy physique, innovative spirit and so on. However, in fact, in the vocational college undergraduate tourism management professional teaching process, the orientation of personnel training is very clear. The tourism management specialty of colleges and universities in colleges and universities is often not much investigation, are based on the theory to teach the main, the lack of practical operation, and the current status of the development of tourism seriously out of line. This led to tourism management graduates in the industry when the difficulties encountered, the employment rate decreased. This also caused the lack of tourism-related personnel, especially the management of talent, so that it affected the overall development of the tourism industry.

\subsection{Innovation and entrepreneurship education corresponding to the lack of teachers}

Innovation and entrepreneurship education as a new educational philosophy, in the way of education has a difference with the traditional theory of teaching, which also requires the school needs to innovate entrepreneurship education related to the screening of teachers. Participating in tourism management professional innovation and entrepreneurship education teachers must have the relevant professional knowledge of tourism management, more importantly, also need to have engaged in the tourism industry's practical experience. However, most teachers tend to be scientific research, have rich experience in classroom teaching, and focus on theoretical research, but there is no shortage of experience in innovation and entrepreneurship education, even in the case of teachers' team of innovation and entrepreneurship education in colleges and universities is inexperienced. For the professional management of tourism industry, the industry must grasp the professional situation, the lack of practical experience of teaching is fatal, according to the script or only focus on theoretical study and research will lead to students into the theory and practice of separation of the problem, tourism management professional to implement and practice this goal.

\subsection{Innovation and entrepreneurship education platform construction is insufficient}

At present, in our country has opened a tourism management professional higher vocational college, innovation and entrepreneurship education has entered the teaching design of colleges and universities, but in reality there are problems. Most colleges and universities innovation and entrepreneurship education platform construction is insufficient, the construction of training base inside and outside the school has shrunk, the whole and the current tourism industry out of touch. Which led to the school although the tourism management professional innovation and entrepreneurship education, but in fact did not achieve the teaching effect. Innovation and entrepreneurship education platform construction is insufficient; students in the theory applied to practice there will be blank area. There are many reasons for the lack of innovation and entrepreneurship education platform, such as lack of funds related to the school, school and enterprise cooperation is not successful, etc., will lead to the existence of short-term educational platform, a direct result of innovation and entrepreneurship education cannot be achieved in some ways to reduce the effectiveness of innovative entrepreneurship education teaching effect.

\section{The reform of tourism management professional innovation and entrepreneurship education}

The innovation of tourism management specialty in higher vocational colleges is aimed at cultivating contemporary innovative talents. It needs to combine the present situation and trend of modern tourism, integrate innovative ideas into daily teaching and actively carry out practical classroom. In the specific teaching process, the contents of the course of tourism management, course 
arrangement, teaching methods and practical courses should be marked in the teaching plan. Tourism management professional innovation and education should be consistent with the tourism industry human resources needs, so that with the times. At the same time, in the traditional management of tourism management should also complete the theoretical basis of learning, and to be practical practice.

\subsection{Clear tourism management professionals training direction}

Clear the direction of tourism management professionals training is to strengthen the first step in innovation and entrepreneurship education. Higher vocational colleges and universities tourism management professional talent training direction, the most fundamental is to adhere to moral education. Moral education is the soul of campus education, tourism management professional is no exception. From the perspective of professional training, tourism management professional innovation and entrepreneurship education training direction is the theory can practice the innovative talents. Colleges and universities need in the existing teaching conditions and innovative business platform on the basis of improving the relevant curriculum system arrangements. The teaching of innovation and entrepreneurship education is based on the theoretical study. Therefore, the arrangement of the theory and practice course should be reasonable when the course is arranged, and the teaching method combined with theoretical study and practice should be paid. In the process of innovation and entrepreneurship teaching, it is possible to simulate the present situation of tourism in the feasible range, to minimize the gap between campus teaching and industry time, and to reduce the possibility of disjunction between students and industry. In addition, the current focus on tourism trends, concerned about the direction of talent gap, the campus tourism management professional final goal is to provide the relevant talents to the tourism industry, natural, the tourism industry needs natural population will become the campus education oriented, the school can be targeted Timely and timely adjustment of education programs.

\subsection{Vigorously expand the innovation and entrepreneurship education teacher team}

In the process of tourism management professional innovation and entrepreneurship education, teachers are undoubtedly the most direct, the greatest impact on the teaching effect. Therefore, the construction of relevant teachers must be taken seriously. In the university to play tourism management professional innovation and entrepreneurship should also both professional and practical experience. Relevant teachers must be a professional source of tourism management, with rich, systematic knowledge of the industry, understand the forefront of the development of industry theory, at the same time with the current experience of the tourism industry, and tourism has its own thinking. In fact, at the same time with these teachers are few, cannot meet all the colleges and universities in China tourism management professional innovation and entrepreneurship education needs. Therefore, the theory can also be separated from the practice class, the theoretical course can continue to the previous teaching model, into the tourism industry frontier knowledge introduction; practice class school can engage in the tourism industry, with rich experience of relevant personnel to school for students teaching, in practice, so that students feel the development of tourism, comparative theory and practice of the gap. In this process, students can not only the theoretical knowledge of the classroom self-practice, to deepen understanding, but also in the tourism industry is engaged in communication with teachers to grasp the development trend of tourism, professional and industry fit, at the same time, in the collision between inside and outside the school, the probability of innovation and entrepreneurship will increase the probability, help to improve students' innovation, entrepreneurial ability, to achieve tourism management professional innovation education teaching objectives.

\subsection{To strengthen the innovation and entrepreneurship education platform}

Higher vocational colleges of tourism management professional innovation and education platform is generally the construction of relevant training base, so that students can have the opportunity to fully practice, in practice, find problems, solve problems, and can sum up experience or even innovation, and ultimately Practice to improve their own innovation and entrepreneurship. The school in the training base construction can be more school-enterprise cooperation. Enterprises are the 
survival and industry, the industry requirements and changes have the most sensitive and most direct response. School-enterprise cooperation can help students to campus training and future work relative to maximize the campus education and social dislocation. In addition, there are many kinds of innovation and entrepreneurship competition in Chinese colleges and universities, the school should encourage students to participate. In the competition, through their own understanding of the industry environment is more conducive to students to stimulate innovation, while the collision with other people in the process there may be opportunities for innovation and entrepreneurship.

\section{Conclusion}

In today's society, the tourism industry has gradually become one of the important industries in economic development. The development of the tourism industry is the demand of the relevant talent. The aim of the undergraduate tourism management specialty is to provide professional talents for the tourism industry. However, with the development of the industry, the tourism industry requires talent not only professional, but also innovation. Innovative education is not only the requirement of educational development, but also the demand of industry development. However, there are some problems in the innovation and entrepreneurship education of tourism management in colleges and universities in our country, which leads to the improvement of the teaching effect of innovation and entrepreneurship education. The training personnel cannot meet the requirements of industry requirements. Therefore, the innovation and entrepreneurship education of the students of tourism management in colleges and universities should be strengthened. The author puts forward three suggestions on tourism management professional innovation and entrepreneurship education reform: clear tourism management personnel training direction, vigorously expand the innovation and entrepreneurship education teacher's team and strengthen the innovation and entrepreneurship education platform. Hope to provide reference for the future development of innovation and entrepreneurship education of Tourism Management Major in Higher Vocational colleges in our country.

\section{Acknowledgements}

This article is the Hainan Provincial Department of Education reform project funding results, the title: Pan-tourism era "4+0" undergraduate tourism management professional innovation and entrepreneurship curriculum resources research, number: Hnjg 2017-63.

\section{References}

[1] C.H. Zhang. Study on the Entrepreneurship of Innovative Entrepreneurship Education in the Curriculum of Tourism Management in Higher Vocational Education [J]. Commercial Stories. 2016

[2] J. Wei. Internet under the background of tourism management professional innovation entrepreneurial ability training [J] .Hubei Adult Education College. 2016 